\title{
Fine and ultrafine particles of the diet: influence on the mucosal immune response and association with Crohn's disease
}

\author{
Miranda C. E. Lomer ${ }^{1 *}$, Richard P. H. Thompson ${ }^{1}$ and Jonathan J. Powell ${ }^{2}$ \\ IGastrointestinal Laboratory, The Rayne Institute, St Thomas' Hospital, Lambeth Palace Road, London SE1 7EH, UK \\ ${ }^{2}$ Department of Nutrition, King's College London, Franklin-Wilkins Building, Stamford Street, London SE1 8WA, UK
}

\begin{abstract}
Crohn's disease is a modern Western disease characterised by transmural inflammation of the gastrointestinal tract. It is of unknown aetiology, but evidence suggests that it results from a combination of genetic predisposition and environmental factors. Bacterial-sized microparticles $(0 \cdot 1-1 \cdot 0 \mu \mathrm{m})$ are potent adjuvants in model antigen-mediated immune responses and are increasingly associated with disease. Microparticles of $\mathrm{TiO}_{2}$ and aluminosilicate accumulate in macrophages of human gut-associated lymphoid tissue where the earliest signs of lesions in Crohn's disease are observed. Dietary microparticles are of endogenous or exogenous origin. Endogenous microparticles dominate and are calcium phosphate (most probably hydroxyapatite), which precipitates in the lumen of the mid-distal gastrointestinal tract due to secretion of $\mathrm{Ca}$ and phosphate in the succus entericus. Exogenous dietary microparticles are contaminants (soil and/or dust) and food additives. $\mathrm{TiO}_{2}$, for example, is a food colourant, and aluminosilicates are anticaking agents, although some aluminosilicates occur as natural contaminants. Food additives alone account for ingestion of approximately $10^{12}$ particles/person per $\mathrm{d}$. Possible mechanisms for the role of exogenous and endogenous dietary microparticles in promoting toleragenic or immune responses of gastrointestinal mucosal phagocytosis are discussed. In a double-blind randomised pilot study we have shown that a diet low in $\mathrm{Ca}$ and exogenous microparticles appears to alleviate the symptoms of ileal Crohn's disease, with a significant $(P=0.002)$ improvement in the Crohn's disease activity index. A multi-centre trial and further mechanistic studies at the cellular level are underway.
\end{abstract}

\section{Dietary microparticles: Crohn's disease}

Fine $(0 \cdot 1-1.0 \mu \mathrm{m}$ diameter $)$ and ultrafine $(<0 \cdot 1 \mu \mathrm{m}$ diameter) particles of the diet, collectively termed microparticles, are increasingly associated with the modern Western lifestyle. The present review considers dietary sources of microparticles, their cellular uptake and effects, and their possible association with the inflammatory bowel disease, Crohn's disease.

\section{Crohn's disease}

Crohn's disease is a chronic relapsing inflammatory bowel disease that is characterised by transmural inflammation anywhere in the gastrointestinal tract, but typically in the distal small intestine (ileum), and/or caecum and large intestine (Table 1). It is often characterised by 'skip lesions', i.e. segments of bowel are affected with normal areas in between. The disease is commonly treated with drugs (e.g. azathioprine, corticosteroids), or liquid polymeric or elemental diets. Surgical removal of diseased bowel is necessary when management has failed, but the disease often recurs, and is then almost always proximal to the anastomosis.

The severity of the disease varies, but it commonly presents with periods of active disease and then remission, although any exacerbating factors are not clear. Both genetic (Hampe et al. 2001; Hugot et al. 2001; Ogura et al. 2001) and environmental factors (Fiocchi, 1998) contribute to the disease. The latter is clearly important since Crohn's disease is almost exclusively a disease of developed countries, but presents also in immigrants from under- 
Table 1. Features of Crohn's disease

\begin{tabular}{l}
\hline Features \\
\hline Peaks in young adults \\
Rare in developing countries \\
Increasing in immigrants to UK \\
Skip lesions \\
Predilection for ileum and/or colon \\
Treatment \\
$\quad$ Drugs \\
Diet \\
$\quad$ Surgery \\
\hline
\end{tabular}

developed countries. Crohn's disease has increased in incidence, especially since the Second World War, and the prevalence is presently about 1:1000 of the population in the Western world (Calkins \& Mendelhoff, 1995).

The first histological signs of disease overlie intestinal lymphoid aggregates (Peyer's patches) and are commonly attributed to the translocation of bacteria and/or macromolecules across the M-cell-rich mucosa (Neutra, 1998), leading to abnormal inflammatory responses. Such observations certainly explain the presence of skip lesions in Crohn's disease and the predominance of distal disease. In addition, these data suggest that macrophages, which phagocytose macromolecules, microparticles and bacteria, may be the primary cell type that is involved; a view that has received much recent support from cellular (Powell et al. 2000; SM Evans and JJ Powell, unpublished results), immunocytochemical (Ellis et al. 1998) and molecular (Hampe et al. 2001; Hugot et al. 2001; Ogura et al. 2001) studies. Recent molecular and genetic studies (Hampe et al. 2001; Hugot et al. 2001; Ogura et al. 2001) implicate a mutated NOD2 protein in disease susceptibility, this protein being an Apaf-1-like molecule with both nucleotide-binding and caspase-recruitment domains, which is exclusively expressed in monocytes. However, environmental factors that trigger and exacerbate disease have not been identified.

Shepherd et al. (1987) presented their findings of 'pigment cells' at the base of Peyer's patches (Fig. 1) in all healthy and diseased samples of human small intestine. Subsequent analysis indicated that these cells contained $\mathrm{Ti}$, $\mathrm{Al}$ and $\mathrm{Si}$ (Shepherd et al. 1987). In a follow-up study we showed that these elements were present as inorganic microparticles, i.e. anatase (a specific polymorph of $\mathrm{TiO}_{2}$ ), kaolinite (a polymorph of aluminosilicate) and other silicates (Powell et al. 1996). These microparticles are of dietary origin, accumulate at the base of Peyer's patches and have been implicated elsewhere in inflammatory disease in susceptible individuals (see p. 125). For these reasons, we have investigated a possible association between inorganic microparticles of the diet and Crohn's disease. More recently, we have widened these investigations to include endogenous lumen microparticles (calcium phosphate) that are degradable and are not accumulated, but still may transiently and frequently interact with mucosal phagocytes.

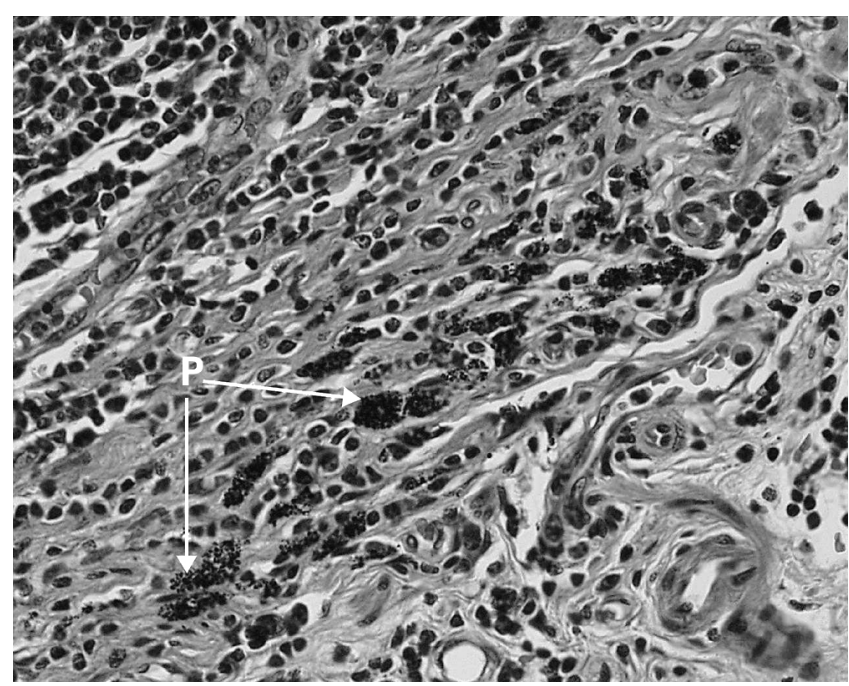

Fig. 1. High-powered light micrograph ( $\times 400$ original) showing the base of a human intestinal lymphoid aggregate. The dark pigmented cells $(\mathrm{P})$ represent $\mathrm{CD}^{+} 8^{+}$macrophages containing numerous granular microparticles of predominantly aluminosilicates and titanium dioxide.

\section{Microparticle-related diseases}

It has become clear that microparticles are associated with increased mortality and morbidity (Samet et al. 2000). Data commonly refer to organic atmospheric particles, such as diesel exhaust, and there are less clear data for inorganic particles, such as aluminosilicates and $\mathrm{TiO}_{2}$, except in geochemically-related diseases. Exposure to freshly-fractured silica is associated with coal miners' pneumoconiosis (Liou et al. 1996), while the aluminosilicate, erionite, causes mesothelioma (Metintas et al. 1999). More interestingly, podoconiosis, which is an obstructive lymphopathy also known as non-filarial elephantiasis, is caused by soil microparticles taken up into the lymphatics of bare-footed agriculturists in tropical Africa (Price, 1990; Harvey et al. 1996). These biologicallyactive soil microparticles are the result of neovolcanic action, and those taken up into the lymphatics are rich in $\mathrm{Al}$, $\mathrm{Si}$ and Ti. Only susceptible individuals go on to develop a latent granulomatous inflammatory disease of the lower limbs, whilst most individuals remain disease free. The potential analogy with microparticles and Crohn's disease of the intestine is interesting.

The pattern of increasing dietary exposure to $\mathrm{TiO}_{2}$ in the Western world (Barksdale, 1966) parallels the prevalence of Crohn's disease, and this relationship has stimulated us to focus on intestinal responses to this particle type (Powell et al. 2000). Although $\mathrm{TiO}_{2}$ is generally considered biologically inert, there are examples of inflammatory reactions to the $\mathrm{TiO}_{2}$ layer that forms on the surface of $\mathrm{Ti}$ metal hip prostheses (Kohilas et al. 1999). The surface layer $\left(\mathrm{TiO}_{2}\right)$ migrates and is taken up by the local cellular environment, possibly with adsorbed self-proteins, thus inducing local immune responses (Ellingsen, 1991). The general evidence of lack of responsiveness to $\mathrm{TiO}_{2}$ in animal 
studies should not be confused with possible abnormal immune responsiveness in genetically-diverse human subjects.

\section{Microparticles in the gastrointestinal lumen}

Microparticles are bacterial-sized non-biological particles which fall into two categories in the gastrointestinal tract, i.e. those of exogenous or endogenous origin. Endogenous microparticles are formed by precipitation in situ in the gastro-intestinal lumen and appear only to be calcium phosphate (most probably hydroxyapatite). Precipitation of other metal ions, such as $\mathrm{Fe}$ and $\mathrm{Al}$, is carefully prevented due to the secretion of low-molecular-weight ligands, proteins and especially mucins into the intestinal lumen (Powell et al. 1999a,b). In contrast, while Ca is maintained in a soluble form in the upper gastrointestinal tract, it coprecipitates with phosphate in the mid-distal gastrointestinal tract forming calcium phosphate microparticles. This process is not a result of non-absorbed dietary $\mathrm{Ca}$, but chiefly due to re-secretion of $\mathrm{Ca}$ and phosphate in the succus entericus of the gastrointestinal mucosa. In contrast, exogenous microparticles are of direct dietary origin and are mainly aluminosilicates and $\mathrm{TiO}_{2}$.

\section{Sources of endogenous microparticles (calcium phosphate)}

The gastrointestinal homeostasis of $\mathrm{Ca}$ is complicated. In healthy individuals net absorption occurs in the proximal small intestine, while net secretion occurs in the mid and distal small intestine, with variable flux in the colon. $\mathrm{Ca}$ secretion therefore occurs primarily in the jejunum and ileum, and is a non-saturable process that mostly follows a Na-dependent paracellular pathway (Favus, 1985). Since water and electrolyte fluxes greatly influence the secretion of Ca (Phillips \& Giller, 1973; Favus, 1985; Metintas et al. 1999), there are large ranges of lumen Ca concentrations both within and between individuals (Phillips \& Giller, 1973; Powell et al. 1994). A median value of $4.2 \mathrm{mM}-\mathrm{Ca}$ in the proximal ileum is quoted (Geigy, 1981) and has been used in our studies of Ca effects on intestinal cells (Powell et al. 2000; SM Evans, P Ashwood, A Warley, F Berisha, RPH Thompson and JJ Powell, unpublished results).

In addition, $\mathrm{PO}_{4}{ }^{3-}$ are actively secreted into the ileum (Favus, 1985), the net result being that calcium phosphate microparticles precipitate in the lumen of the mammalian gastrointestinal tract (Schedl et al. 1967, 1968; Powell et al. $1999 b$ ). This precipitate does not re-dissolve in the lumen and, therefore, is not recycled for $\mathrm{Ca}^{2+}$ absorption (Schedl et al. 1968). In animals with normal Ca status the precipitate comprises about one-third of the secreted $\mathrm{Ca}$ (Schedl et al. 1968).

Recently, we characterised the lumen calcium phosphate precipitate in rats (Powell et al. 1999b), in which it makes up the majority of the inorganic particulate content of the gastrointestinal lumen, with all particles smaller than $2 \mu \mathrm{m}$ in diameter (i.e. mostly microparticles). $\mathrm{Ca}: \mathrm{P}$ is approximately 5:3 and therefore strongly indicates formation of hydroxyapatite (pentacalcium mono-hydroxyorthophosphate; $\left.\mathrm{Ca}_{5}(\mathrm{OH})\left(\mathrm{PO}_{4}\right)_{3}\right)$.

\section{Endogenous microparticles and intestinal cells}

The role of this $\mathrm{Ca}$ and phosphate secretion and coprecipitation is unclear, although some researchers have proposed that it contributes to the inhibition of cytotoxicity by faecal water (Lapré et al. 1991; Welberg et al. 1993). We propose an additional mechanism of action that involves immune tolerance. It is clear that freshly-precipitated calcium phosphate (most probably hydroxyapatite) can bind lumen biomolecules, including toxins and antigens (Lapré et al. 1991; Welberg et al. 1993; Govers et al. 1994). The micron-sized particles of calcium phosphate are likely, in part, to be scavenged by the M-cell-rich mucosa overlying intestinal lymphoid aggregates. This $\mathrm{Ca}$ species is acid soluble (Schedl et al. 1968), and would be re-dissolved in the acidic phagosomes of phagocytic mononuclear cells of the intestinal mucosa. This process leads to rapid cell death, probably apoptosis (SM Evans and JJ Powell, unpublished results), as elevated intracellular $\mathrm{Ca}$ is involved in a number of apoptotic pathways (Krebs, 1998; Tagliarino et al. 2001). It is possible, therefore, that calcium phosphate microparticles, carrying antigen on their surface or co-precipitated within their matrix, may induce immune tolerance rather than active immunity, as the phagocytic antigen-presenting cell undergoes cell death during antigen presentation.

A consequence of this induced apoptosis, however, appears to be the concomitant release of the proinflammatory cytokine interleukin (IL) $1 \beta$ which, possibly, is essential for cell-cell signalling during the apoptotic process (Powell et al. 2000; SM Evans and JJ Powell, unpublished results). Surprisingly, our present data suggest that this common pathway of cell death and IL-1 $\beta$ release is not mediated through caspase 1 (IL-1 converting enzyme), since inhibition of caspase 1 activation inhibits IL- $1 \beta$ secretion but does not affect cell death ( $\mathrm{P}$ Ashwood and JJ Powell, unpublished results). Clearly, other caspases are involved, and further investigations are underway. Nonetheless, the observation that particulate calcium phosphate induces IL-1 $\beta$ secretion in peripheral and intestinal mononuclear cells (SM Evans and JJ Powell, unpublished results) suggests that in the already-inflamed bowel, such as in Crohn's disease, this process could add to the burden of pro-inflammatory cytokines.

\section{Sources of exogenous dietary microparticles}

Exogenous microparticles occur as natural dietary contaminants (typically dust and soil) and man-made food additive or pharmaceutical excipients. An average individual's intake in the UK amounts to $>10^{12}$ microparticles/d (see p. 126), and these microparticles are resistant to gastrointestinal degradation. Furthermore, microparticles have large adsorptive negatively-charged surfaces that bind biomolecules of the gastrointestinal lumen. Once ingested, some microparticles are absorbed across the gastrointestinal mucosa and some accumulate in the macrophages (pigment cells) described earlier. 
In the UK the daily dietary consumption of $\mathrm{TiO}_{2}$ and aluminium sodium silicate (E554) is estimated as 5.4 and $0.5 \mathrm{mg} /$ person per d respectively (Ministry of Agriculture, Fisheries and Food, 1993). $\mathrm{TiO}_{2}$ added to food has a mean diameter of $0.2 \mu \mathrm{m}$, and thus the above-average daily intake translates to $10^{12}$ particles/person per d (Churg, 1996). Pharmaceutical and micronutrient supplements, which frequently contain $\mathrm{TiO}_{2}$ and aluminosilicates as excipients, further increase the intake of microparticles, but estimates of this additional intake are not yet available.

Titanium dioxide. $\mathrm{TiO}_{2}$ is an intense whitening and brightening agent used in the food and pharmaceutical industries (Table 2). In foods, it is primarily used to restore whiteness in creamy products (e.g. salad dressings) and in confectionery, where it sometimes forms a barrier between layers of different colours (e.g. soft-centred sweets with a crisp shell). Typical sources of $\mathrm{TiO}_{2}$ are confectionery, white-coloured sauces and dressings, and non-dairy creamers. In the pharmaceutical industry $\mathrm{TiO}_{2}$ is predominantly used as an opacity agent.

Quantitative evaluation of foods containing $\mathrm{TiO}_{2}$ is difficult; first, because food labels do not have to provide quantitative data on food additives and second, because there are exceptions to the legislation that states food additives must be identified on food labels. For example, labelling is not required when additives perform no additive function in the final product and are used in compound ingredients that make up less than $25 \%$ of the finished product (Lomer et al. 2000). In addition, of course, many foods purchased as ready-to-eat do not carry food labels.

$\mathrm{TiO}_{2}$ (E171) can be used in specific food products at quantum satis, which indicates that there is no maximum level specified (Jukes, 1997). However, following good manufacturing practice, food manufacturers confirm that $\mathrm{TiO}_{2}$ is used at levels no greater than that necessary to perform its function, and is generally used at $\leq 0.2 \%$ (w/w) of a product. Again, there are exceptions to this practice and, as illustrated in Table 2, use of this additive is highly variable, making accurate estimates of intake yet more difficult. Indeed, an individual's dietary choices or preferences will dictate their intestinal exposure to $\mathrm{TiO}_{2}$. In extreme cases just one portion of a salad dressing $(225 \mathrm{mg}$ $\mathrm{TiO}_{2}$; Lomer et al. 2000) could exceed the average daily intake of $5.4 \mathrm{mg}$ (Ministry of Agriculture, Fisheries and Food, 1993) by $>40$-fold.

Silicates and aluminosilicates. Silicates and aluminosilicates are used widely in the food industry to prevent poor flow or 'caking', especially in powdered products (Table 3). They are used to overcome difficulties associated with moisture, temperature and compression, all of which can lead to agglomeration. Usually silicates and aluminosilicates are added to food products at $0 \cdot 1-1 \%(\mathrm{w} / \mathrm{w})$ to enable free flow, and are commonly used in vending machine powders, milk and cream powder substitutes, cheese and sugar. They can also be used as carriers for flavourings. Further data on the silicate and aluminosilicate content of food products are not yet available.

\section{Exogenous microparticles and intestinal cells}

Submicron-sized particles can be surprisingly well absorbed in the gastrointestinal tract, with notable uptake occurring at the M-cell-rich mucosa overlying intestinal lymphoid aggregates (Neutra, 1998). In addition, uptake by enterocytes and paracellular passage have been demonstrated, indicating that microparticle translocation may also occur across the regular intestinal epithelium (Desai et al. 1996). Although this process occurs more diffusely than at the surface of intestinal lymphoid aggregates, total uptake may be important due to the large surface area of the epithelium (Desai et al. 1996). Exogenous aluminosilicates (mostly kaolinite) and $\mathrm{TiO}_{2}$ (anatase) are then passed to, and retained by, underlying phagocytes (pigment cells; see p. 124) of the mucosa. Both kaolinite and anatase are highly resistant to chemical degradation and are biologically inert, so neither of these microparticles appear to stimulate mononuclear cells in vitro or in vivo. However, the effects of microparticles on intestinal phagocytes should not be considered in isolation.

In contrast to most soil-derived microparticles, manmade microparticles (e.g. food additives) have active charged surfaces that avidly adsorb lumen biomolecules as they traverse the gastrointestinal tract (Govers et al. 1994). A 'Trojan horse' mechanism may operate whereby lumen toxins (e.g. bacterial lipopolysaccharide) or antigens (e.g. bacterial and food proteins) are transported into the intestinal mucosa on the surface of dietary microparticles. The effect of particulates on intestinal cellular responses to antigen has not yet been investigated, but data from cell lines suggest that antigen presentation may be markedly altered.

The processing of particle-bound antigen is qualitatively and quantitatively distinct from that of soluble antigen (Kovacsovics-Bankowski et al. 1993; Sedlik et al. 1997;

Table 2. The varying contents of titanium dioxide added to foods; examples for each group are shown for the minimum (min) and maximum (max) levels of titanium dioxide found in an analytical survey (Lomer et al. 2000)

\begin{tabular}{|c|c|c|c|}
\hline Food group & Food product ${ }^{\star}$ & $\mathrm{TiO}_{2}$ (mg/portion) & Portion size $(\mathrm{g})$ \\
\hline Confectionery & $\begin{array}{l}\text { Mini Eggs (Cadbury Ltd; min) } \\
\text { Cake Icing (Supercook; max) }\end{array}$ & $0-55$ & $15-30$ \\
\hline Sauces & $\begin{array}{l}\text { Mustard (Colman's of Norwich; min) } \\
\text { Italian Dressing (Hellmann's; max) }\end{array}$ & $0-225$ & $\begin{array}{c}30 \\
(1 \mathrm{tbs})\end{array}$ \\
\hline Non-dairy creamers & $\begin{array}{l}\text { Coffeemate (Nestlé; min) } \\
\text { Teamate (Nestlé; max) }\end{array}$ & $<0.1-3.5$ & $\begin{array}{c}4 \cdot 5 \\
(1 \mathrm{tsp})\end{array}$ \\
\hline
\end{tabular}

tbs, tablespoon; tsp, teaspoon.

${ }^{*}$ Cadbury Ltd, Bourneville, Birmingham, UK; Supercook, Leeds, UK; Colman's of Norwich, Norwich, Norfolk, UK; Hellmann's, Unilever Bestfoods (UK) Ltd, Crawley,

West Sussex, UK; Nestlé SA, Vevey, Switzerland. 
Table 3. Typical food sources of aluminosilicates

Aluminosilicates E554, E556, E559

lcing sugar

Savoury rice and noodles

Non-dairy creamers

Chewing gum

Powdered foods

Vending machine drinks

Song \& Harding, 1996; Vidard et al. 1996). Particulate antigen, processed and presented by macrophages or Bcells, stimulates major histocompatibility complex (MHC) class II-restricted T-cell hybrids up to $10^{5}$-fold more efficiently than soluble antigen (Vidard et al. 1996). Macrophages process a greater size range of particulate antigens compared with B-cells, but both these phagocytic antigenpresenting cells generate epitopes distinct from those from soluble antigen. Furthermore, Sedlik et al. (1997) showed that both T-helper 1 and 2 cytokines were produced in response to immunisation with particle-bound antigen, but in the presence of appropriate cofactors (e.g. IL-12) T-helper 1 cells were selectively activated (Sedlik et al. 1997). In addition, particulate antigen, unlike soluble antigen, may gain entry to an alternative class I MHC pathway, most notably in macrophages, and a number of mechanisms have been proposed (Song \& Harding, 1996). Following phagocytosis, solubilised antigen may escape the phagosome and enter conventional cytosolic class I MHC processing. Alternatively, a post-golgi combination of phagocytosed degraded antigen with class I MHC may occur either intravesicularly or at the cell surface following regurgitation. Recent data support an intravesicular mechanism (Song \& Harding, 1996), and although the trafficking of nascent MHC I is rare, conventionally-coupled class I MHC-peptide may undergo $\mathrm{pH}$ induced de-coupling during passage of the acidic trans-golgi network, allowing peptide exchange (Stryhn et al. 1996).

Fewer studies have specifically investigated the processing of particulate antigen in vivo, although Maloy et al (1994) have shown that oral ovalbumin, delivered in poly(lactide-co-glycolide) particles, induced ovalbuminspecific cytotoxic T-lymphocyte responses and generated intestinal immunoglobulin A (Maloy et al. 1994). These processes are summarised in Fig. 2 and, clearly, the influence of the physical form of antigen in dictating cellular uptake and processing in the gastrointestinal tract should be considered.

To date much of our work has considered the influence of microparticle-toxin conjugates, rather than microparticleantigen conjugates, on intestinal phagocyte function. Bacterial lipopolysaccharide (LPS) is abundant in the lumen of the gastrointestinal tract, and is a potent stimulant of monocytes. Monocytes recruited to the intestinal mucosa, however, undergo phenotypic and functional changes during maturation and become LPS-tolerant macrophages. One potential way to overcome LPS tolerance may be its delivery to the cell in a particulate form (e.g. as whole bacteria or adsorbed to microparticle surfaces). Pro-inflammatory cytokines such as IL-1 $\beta$, tumour necrosis factor $\alpha$ and IL- 6 are secreted by intestinal phagocytes in response to particulate LPS. However, one confounding factor is that adsorption of LPS to the surface of $\mathrm{TiO}_{2}$ is facilitated by a $\mathrm{Ca}^{2+}$ bridge and, again, $4 \mathrm{mM}-\mathrm{Ca}$ has been used in much of our work. Thus, in the mixed LPS-anatase-Ca system the relative contributions of particulate $\mathrm{Ca}$ and particulate LPS to cellular secretion of inflammatory cytokines remains to be established. Nonetheless, the data clearly indicate that food additive $\mathrm{TiO}_{2}$ amplifies cellular responses to $\mathrm{Ca}$ and/or LPS.

Thus, investigations with bacterial LPS or antigens indicate that microparticles can act both quantitatively and qualitatively as adjuvants for cytokine responses and T-cell proliferative responses induced by macrophages. Whether there is an underlying dysfunction in Crohn's disease cells to such particulate adjuvant effects remains to be established.

\section{Dietary exclusion of microparticles in Crohn's disease}

There are no data on dietary microparticle intakes in health or disease. However, diet has a major effect on the intestinal environment (Russel et al. 1998), and perhaps the adoption of Western dietary habits plays a part in the aetiology or pathogenesis of Crohn's disease. Indeed, the most consistent dietary finding relates to sugar consumption, and studies have found that patients with Crohn's disease have a significantly higher intake in comparison with control subjects $(P<0.005$, Martini \& Brandes, 1976; $P<0.05$, Thornton et al. 1985). A high intake of sugar is often associated with diets high in convenience foods and confectionery, and these foods often contain dietary microparticles. Recently, we have conducted a case-control dietary study to assess differences in dietary microparticle intake, and our data confirm increased exposure to refined carbohydrate in patients with Crohn's disease compared with healthy controls. Whether this finding will reflect differences in dietary microparticle intake is being investigated (MCE Lomer and JJ Powell, unpublished results).

Elemental diets are effective in the treatment of active Crohn's disease (Mansfield et al. 1995) and the maintenance of disease remission (Wilschanski et al. 1996), and our analyses show them also to be free of microparticles (MCE Lomer and JJ Powell, unpublished results). These diets are as efficacious as conventional drug therapy (O’Morain et al. 1984; Okada et al. 1990; Zoli et al. 1997), and in adolescents and children are used in preference to treatment with corticosteroids or immunosuppressants (Wilschanski et al. 1996). Dietary compliance is often a problem, as large volumes are required to meet nutritional requirements, and the feeds can be unpalatable. Once disease remission is achieved, usually within 2-8 weeks, re-introduction of normal food is a gradual process, using an 'exclusion diet regimen' which introduces a single food each day and excludes any food that may be associated with symptoms of abdominal pain and/or diarrhoea (Riordan et al. 1993). Generally, these re-introduction diets start with foods that are typically well tolerated in Crohn's disease, are usually in an unprocessed form, and are thus low in microparticles. 


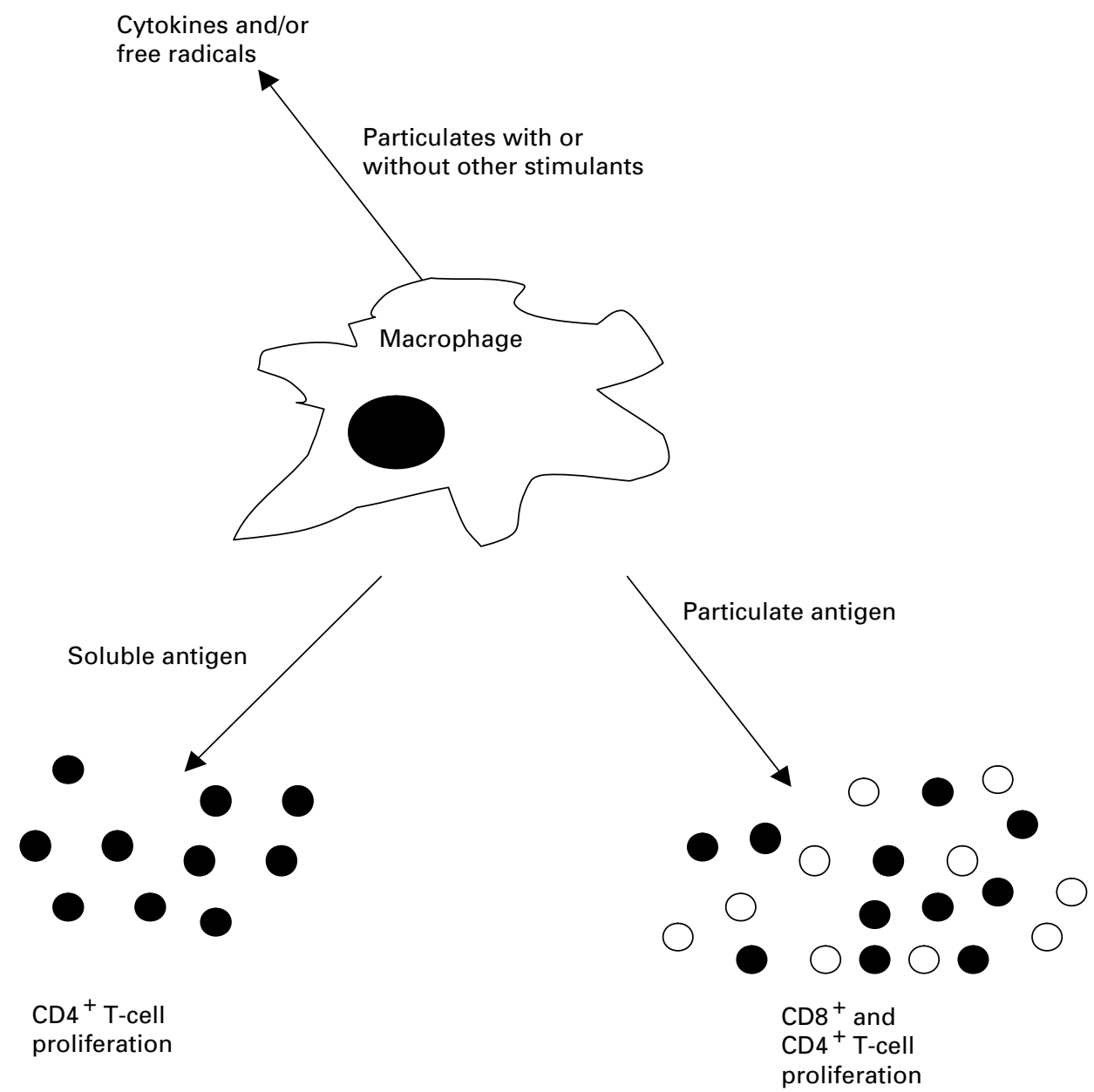

Fig. 2. Macrophages have three main immunological functions, i.e. the generation of reactive oxygen species (free radicals), the secretion of immunomodulatory cytokines and the stimulation of T-cell proliferation. Cytokine and/or free radical production may be enhanced by microparticles. In addition, soluble antigen, which normally is presented in the context of class II major histocompatibility complex (MHC) molecules (stimulating CD4+ T-cell amplification), can be adsorbed to and co-phagocytosed with microparticles. This process leads to the formation of particulate antigen, the presentation of which may then be enhanced with class II MHC molecules compared with soluble antigen or switched to class I MHC molecules leading to $\mathrm{CD}^{+} \mathrm{T}$-cell proliferation. Thus, microparticles may act as adjuvants for cytokine secretion or antigen presentation.

To establish whether a reduction in lumen microparticles can contribute to disease remission a double-blind pilot dietary study was undertaken. Patients with active ileal Crohn's disease, treated with corticosteroids, were randomised to receive dietary advice on either a diet low in microparticles (trial) or a diet unrestricted in microparticles (control) for 4 months (nine subjects per group completed the treatment; Lomer et al. 2001). Dietary advice for the low microparticle intake (trial group) included: (1) avoidance of the inorganic exogenous microparticles, $\mathrm{TiO}_{2}$ and aluminosilicates; (2) limiting dietary $\mathrm{Ca}$ intake to $400 \mathrm{mg} / \mathrm{d}$ (lower reference nutrient intake; Department of Health, 1991); (3) meeting the dietary reference values for all other nutrients (Department of Health, 1991). The unrestricted microparticle diet (control group) were advised on how to meet their dietary reference values for all nutrients (Department of Health, 1991). Both groups were recommended to avoid fibrous fruit and vegetables, as indicated for patients with structuring disease (Ballegaard et al. 1997), and equal time was spent in advising all patients.

Fig. 3 summarises the data after 4 months' treatment, when a significant $(P=0.002)$ reduction in the Crohn's disease activity index (a score derived from patient symptoms for the preceding $7 \mathrm{~d}$ and current clinical data; Best et al. 1976) was observed in the trial group by the end of the study, as compared with results in the control group (Lomer et al. 2001). The efficacy of this diet is now being assessed in a multi-centre randomised double-blind placebo-controlled trial, but the pilot study provides some early evidence for a role for lumen microparticles in disease exacerbation.

Indeed, diversion of the faecal stream can help maintain disease remission in patients with Crohn's disease following surgical removal of the diseased bowel, while following re-anastomosis the disease recurs (Rutgeerts $\mathrm{et} \mathrm{al}$. 1991). As the pilot diet was low in $\mathrm{TiO}_{2}$, aluminosilicates and $\mathrm{Ca}$, the relative role of exogenous microparticles and 


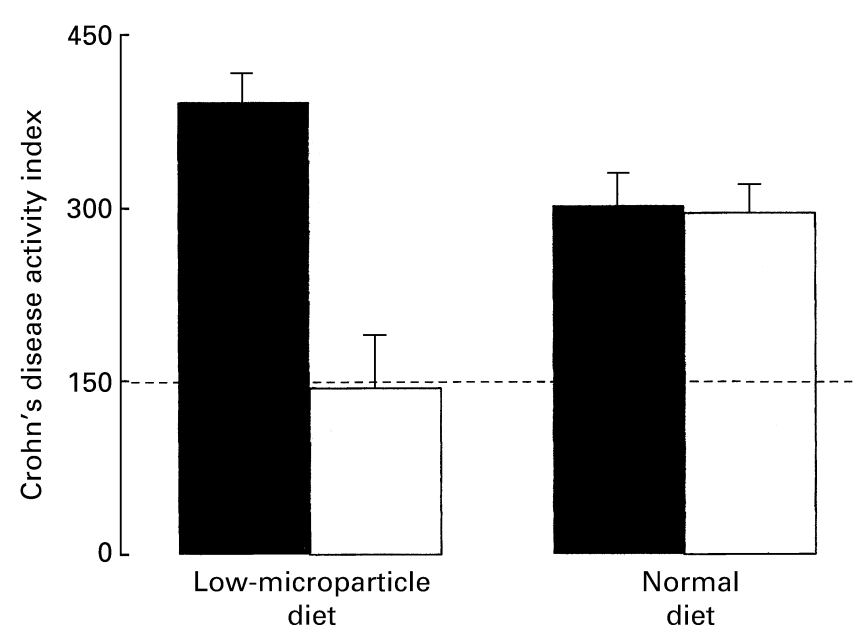

Fig. 3. The reduction in the Crohn's disease activity index (a score derived from patient symptoms for the preceding $7 \mathrm{~d}$ and current clinical data; Best et al. 1976) from entry ( $\square$ ) to completion ( $\square$; four months) for a low-microparticle diet (trial; $n$ 9) compared with a normal microparticle diet (control; $n 9$ ) in Crohn's disease. Disease remission is identified as a score of $<150(---)$ Values are means with their standard errors represented by vertical bars.

calcium phosphate in exacerbating disease is unclear, but this factor is presently being addressed in the multi-centre study.

In conclusion, dietary microparticles occur in two distinct forms; exogenous microparticles are of dietary origin, are resistant to degradation, have little effect on intestinal cells per se, but can bind lumen biomolecules and act as adjuncts in their cellular stimulation. In contrast, endogenous $\mathrm{Ca}$ microparticles (most probably hydroxyapatite) precipitate in situ in the gastrointestinal lumen, are acid labile and broken down by phagocytes, where they can induce IL-1 $\beta$ release and cellular apoptosis. Whether such microparticles can contribute to the ongoing inflammation of Crohn's disease, which is a modern Western inflammatory bowel disease driven by dysfunctional macrophages, remains to be established.

\section{Acknowledgements}

M.C.E.L. is a research training fellow funded by the NHS Executive London Regional Office.

\section{References}

Ballegaard M, Bjergstrom A, Brondum S, Hylander E, Jensen L \& Ladefoged K (1997) Self-reported food intolerance in chronic inflammatory bowel disease. Scandinavian Journal of Gastroenterology 32, 569-571.

Barksdale J (1996) Titanium - Its Occurence, Chemistry and Technology. New York: Ronald.

Best WR, Becktel JM, Singleton JW \& Kern F (1976) Development of a Crohn's disease activity index. National Cooperative Crohn's Disease Study. Gastroenterology 70, 439-444.
Calkins BM \& Mendelhoff AI (1995) Inflammatory Bowel Disease Baltimore, MD: Williams \& Wilkins.

Churg A (1996) The uptake of mineral particles by pulmonary epithelial cells. American Journal of Respiratory and Critical Care Medicine 154, 1124-1140.

Department of Health (1991) Dietary Reference Values for Food Energy and Nutrients for the United Kingdom. Report on Health and Social Subjects no. 41. London: H.M. Stationery Office.

Desai MP, Labhasetwar V, Amidon GL \& Levy RJ (1996) Gastrointestinal uptake of biodegradable microparticles: effect of particle size. Pharmaceutical Research 13, 1838-1845.

Ellingsen JE (1991) A study on the mechanism of protein adsorption to $\mathrm{TiO}_{2}$. Biomaterials 12, 593-596.

Ellis RD, Goodlad JR, Limb GA, Powell JJ, Thompson RP \& Punchard NA (1998) Activation of nuclear factor kappa B in Crohn's disease. Inflammation Research 47, 440-445.

Favus MJ (1985) Factors that influence absorption and secretion of calcium in the small intestine and colon. American Journal of Physiology 248, 147-157.

Fiocchi C (1998) Inflammatory bowel disease: etiology and pathogenesis. Gastroenterology 115, 182-205.

Geigy (1981) Geigy Scientific Tables, vol. 1, Units of Measurement, Body fluids, Composition of the Body, Nutrition. Basle, Switzerland: Ciba-Geigy Ltd.

Govers MJAP, Termont DSML, Aken GAV \& Van der Meer R (1994) Characterization of the adsorption of conjugated and unconjugated bile acids to insoluble, amorphous calcium phosphate. Journal of Lipid Research 35, 741-748.

Hampe J, Cuthbert A, Croucher PJ, Mirza MM, Mascheretti S, Fisher S, Frenzel H, King K, Hasselmeyer A, MacPherson AJ, Bridger S, van Deventer S, Forbes A, Nikolaus S, Lennard-Jones JE, Foelsch UR, Krawczak M, Lewis C, Schreiber S \& Mathew CG (2001) Association between insertion mutation in NOD2 gene and Crohn's disease in German and British populations. Lancet 357, 1925-1928.

Harvey RSJ, Powell JJ \& Thompson RPH (1996) A review of the geochemical factors linked to podoconiosis. Environmental Geochemistry and Health 113, 255-260.

Hugot JP, Chamaillard M, Zouali H, Lesage S, Cezard JP, Belaiche J, Almer S, Tysk C, O'Morain CA, Gassull M, Binder V, Finkel Y, Cortot A, Modigliani R, Laurent-Puig P, Gower-Rousseau C, Macry J, Colombel JF, Sahbatou M \& Thomas G (2001) Association of NOD2 leucine-rich repeat variants with susceptibility to Crohn's disease. Nature 411, 599-603.

Jukes DJ (1997) Food Legislation of the UK. Oxford: ButterworthHeinemann.

Kohilas K, Lyons M, Lofthouse R, Frondoza CG, Jinnah R \& Hungerford DS (1999) Effect of prosthetic titanium wear debris on mitogen-induced monocyte and lymphoid activation. Journal of Biomedical Material Research 47, 95-103.

Kovacsovics-Bankowski M, Clark K, Benacerraf B \& Rock KL (1993) Efficient major histocompatibility complex class I presentation of exogenous antigen upon phagocytosis by macrophages. Proceedings of the National Academy of Sciences USA 90, 4942-4946.

Krebs J (1998) The role of calcium in apoptosis. Biometals 11, $375-382$.

Lapré JA, De Vries HT \& Van der Meer R (1991) Dietary calcium phosphate inhibits cytotoxicity of fecal water. American Journal of Physiology 261, 907-912.

Liou SH, Shih WY, Chen YP \& Lee CC (1996) Pneumoconiosis and pulmonary function defects in silica-exposed fire brick workers. Archives of Environmental Health 51, 227-233.

Lomer MC, Harvey RS, Evans SM, Thompson RP \& Powell JJ (2001) Efficacy and tolerability of a low microparticle diet in a double blind, randomized, pilot study in Crohn's disease. 
European Journal of Gastroenterology and Hepatology 13, 101-106.

Lomer MC, Thompson RP, Commisso J, Keen CL \& Powell JJ (2000) Determination of titanium dioxide in foods using inductively coupled plasma optical emission spectrometry. Analyst 125, 2339-2343.

Maloy KJ, Donachie AM, O'Hagan DT \& Mowat AM (1994) Induction of mucosal and systemic immune responses by immunization with ovalbumin entrapped in poly(lactide-co-glycolide) microparticles. Immunology 81, 661-667.

Mansfield JC, Giaffer MH \& Holdsworth CD (1995) Controlled trial of oligopeptide versus amino acid diet in treatment of active Crohn's disease. Gut 36, 60-66.

Martini GA \& Brandes JW (1976) Increased consumption of refined carbohydrates in patients with Crohn's disease. Klinische Wochenschrift 54, 367-371.

Metintas M, Hillerdal G \& Metintas S (1999) Malignant mesothelioma due to environmental exposure to erionite: follow-up of a Turkish emigrant cohort. European Respiratory Journal 13, 523-526.

Ministry of Agriculture Fisheries and Food (1993) Dietary Intake of Food Additives in the UK: Initial Surveillance. Food Surveillance Paper no. 37. London: H.M. Stationery Office.

Neutra MR (1998) Current concepts in mucosal immunity v. role of $M$ cells in transepithelial transport of antigens and pathogens to the mucosal immune system. American Journal of Physiology 274, 785-791.

O'Morain C, Segal AW \& Levi AJ (1984) Elemental diet as primary treatment of acute Crohn's disease: a controlled trial. British Medical Journal 288, 1859-1862.

Ogura Y, Bonen DK, Inohara N, Nicolae DL, Chen FF, Ramos R, Britton H, Moran T, Karaliuskas R, Duerr RH, Achkar JP, Brant SR, Bayless TM, Kirschner BS, Hanauer SB, Nunez G \& Cho JH (2001) A frameshift mutation in NOD2 associated with susceptibility to Crohn's disease. Nature 411, 603-606.

Okada M, Yao T, Yammamoto K, Takenaka K, Imamura K, Maeda K \& Fujita K (1990) Controlled trial comparing an elemental diet with prednisolone in the treatment of active Crohn's disease. Hepatogastroenterology 37, 72-80.

Phillips SF \& Giller J (1973) The contribution of the colon to electrolyte and water conservation in man. Journal of Laboratory and Clinical Medicine 81, 733-746.

Powell JJ, Ainley CC, Harvey RS, Mason IM, Kendall MD, Sankey EA, Dhillon AP \& Thompson RP (1996) Characterisation of inorganic microparticles in pigment cells of human gut associated lymphoid tissue. Gut 38, 390-395.

Powell JJ, Harvey RS, Ashwood P, Wolstencroft R, Gershwin ME \& Thompson RP (2000) Immune potentiation of ultrafine dietary particles in normal subjects and patients with inflammatory bowel disease. Journal of Autoimmunity 14, 99-105.

Powell JJ, Jugdaohsingh R \& Thompson RP (1999a) The regulation of mineral absorption in the gastrointestinal tract. Proceedings of the Nutrition Society 58, 147-153.

Powell JJ, Whitehead MW, Ainley CC, Kendall MD, Nicholson JK \& Thompson RP (1999b) Dietary minerals in the gastrointestinal tract: hydroxypolymerisation of aluminium is regulated by luminal mucins. Journal of Inorganic Biochemistry 75, 167-180.

Powell JJ, Whitehead MW, Lee S \& Thompson RPH (1994) Mechanisms of gastrointestinal absorption: Dietary minerals and the influence of beverage ingestion. Food Chemistry 51, 381-388.

Price EW (1990) Podiconiosis: Non-filarial Elephantiasis. Oxford: Oxford University Press.
Riordan AM, Hunter JO, Cowan RE, Crampton JR, Davidson AR, Dickinson RJ, Dronfield MW, Fellows IW, Hishon S \& Kerrigan GN (1993) Treatment of active Crohn's disease by exclusion diet: East Anglian multicentre controlled trial. Lancet 342, 1131-1134.

Russel MG, Engels LG, Muris JW, Limonard CB, Volovics A, Brummer RJ \& Stockbrugger RW (1998) Modern life in the epidemiology of inflammatory bowel disease: a case-control study with special emphasis on nutritional factors. European Journal of Gastroenterology and Hepatology 10, 243-249.

Rutgeerts P, Goboes K, Peeters M, Hiele M, Penninckx F, Aerts R, Kerremans R \& Vantrappen G (1991) Effect of faecal stream diversion on recurrence of Crohn's disease in the neoterminal ileum. Lancet 338, 771-774.

Samet JM, Dominici F, Curriero FC, Coursac I \& Zeger SL (2000) Fine particulate air pollution and mortality in 20 U.S. cities, 1987-1994. New England Journal of Medicine 343, 1742-1749.

Schedl HP, Osbaldiston GW \& Mills IH (1967) Role of intraluminal precipitation in secretion of small intestinal calcium and phosphate in the dog. Nature 215, 198-199.

Schedl HP, Osbaldiston GW \& Mills IH (1968) Absorption, secretion, and precipitation of calcium in the small intestine of the dog. American Journal of Physiology 214, 814-819.

Sedlik C, Deriaud E \& Leclerc C (1997) Lack of Th1 or Th2 polarization of $\mathrm{CD} 4^{+} \mathrm{T}$ cell response induced by particulate antigen targeted to phagocytic cells. International Immunology 9, 91-103.

Shepherd NA, Crocker PR, Smith AP \& Levison DA (1987) Exogenous pigment in Peyer's patches. Human Pathology 18, 50-54.

Song R \& Harding CV (1996) Roles of proteasomes, transporter for antigen presentation (TAP), and $\beta 2$-microglobulin in the processing of bacterial or particulate antigens via an alternative class I MHC processing pathway. Journal of Immunology 156, 4182-4190.

Stryhn A, Pedersen L, Romme T, Olsen AC, Nissen MH, Thorpe CJ \& Buus S (1996) $\mathrm{pH}$ dependence of MHC class I-restricted peptide presentation. Journal of Immunology 156, 4191-4197.

Tagliarino C, Pink JJ, Dubyak GR, Nieminen AL \& Boothman DA (2001) Calcium is a key signaling molecule in beta-lapachonemediated cell death. Journal of Biological Chemistry 276, 19150-19159.

Thornton JR, Emmett PM \& Heaton KW (1985) Smoking, sugar, and inflammatory bowel disease. British Medical Journal 290, 1786-1787.

Vidard L, Kovacsovics-Bankowski M, Kraeft SK, Chen LB, Benacerraf B \& Rock KL (1996) Analysis of MHC class II presentation of particulate antigens by B lymphocytes. Journal of Immunology 156, 2809-2818.

Welberg JWM, Kleibeuker JH, Van der Meer R, Kuipers F, Cats A, Van Rijsbergen HDSMLT, Boersma-Van Ek W, Vonk RJ, Mulder NH \& De Vries EGE (1993) Effect of oral calcium supplementation on intestinal bile and cytolytic activity of fecal water in patients with adenomatous polyps of the colon. European Journal of Clinical Investigation 23, 63-68.

Wilschanski M, Sherman P, Pencharz P, Davis L, Corey M \& Griffiths A (1996) Supplementary enteral nutrition maintains remission in paediatric Crohn's disease. Gut 38, 543-548.

Zoli G, Care M, Parazza M, Spano C, Biagi PL, Bernardi M \& Gasbarrini G (1997) A randomized controlled study comparing elemental diet and steroid treatment in Crohn's disease. Alimentary Pharmacology and Therapeutics 11, 735-740. 